\title{
Paradoxes of virology: problems and tasks
}

\author{
A. Boiko, \\ Academician of the NAAS, Doctor of Biological Sciences \\ Institute of Agroecology and Environmental Management of the NAAS
}

The purpose. To show structure and function of pathogens of virus nature on the basis of own researches and researches carried out together with pupils-virologists and scientists of specialized laboratories of researches as well as analysis of results of studying viruses of different taxonomic groups. To present a substantiation of problems and tasks in the field of virology. Methods. Virologic, ecological, molecular and other specialized techniques in versatile experiments (electronic microscopy, IFA, PCR, culture of tissues, mathematical modelling, etc.). Results. Screening of virus infections of various organisms is made. On separate modelling systems it is opened nocuity of causal organisms of diseases and their modern molecular-biological properties, ubiquity. Viruses also are considered as vector systems of transfer of biological information in technologies of different levels of complexity. Problems with virus infections in agrarian and industrial complex, as well as virologic situations on state level are presented. Conclusions. At the state level it is necessary to change the attitude to development of virologic researches. Control of virus infections, their diagnostics and prophylaxis demand highly skilled experts, modern understanding of the role of viruses in nature, health protection, agriculture, defensive industry.

Key words: viruses, ecology, biotechnological processes, vaccines, agrarian and industrial complex.

It is difficult to estimate various scientific achivements exluding virological development. Virology originated in Ukraine.In 1892 Dmitry Ivanovsky discovered pathogen which induced tobacco mosaic and in 1903 he defended his doctoral dissertation on the topic of mosaic illness of tobacco at St. Volodymyr's University (Kiev). Later mosaic pathogen got the name «virus» (virus- poison). It should be admitted that viruses are ubiquitous biological systems, which were adapted to relevant organisms while evolution and under certain conditions can cause enormous damage to nature and destroy the living objects of different taxonomic groups. Recently Earth planet loses its ability to control adaptation of the relevant viruses to certain host organisms. "Diffuse porridge" of different variants of viruses" spontaneously " and often purposefully induces these pathogens to different types of hybridization giving rise to phenomena of variability and unpredictable pathology in humans, animals, plants, which they cause in an unbalanced environment [1,3].

Business nworld for various reasons often neglects the laws of nature in destructive ways trying to reach the single goal - financial gain. The results are wealth and poverty, which create new complicated conflicts of life under appropriate conditions. Harmful factors of anthropogenic pollution and their impact on living systems appears. Critical impoverishment of the population morality towards to the nature state is growing [1].

Under such circumstances most international and native legislative acts about the preservation of natural resources and life on the earth are just loud ones statements, which do not allow basing on an objective assessment of the complex ecological situation of the biosphere to create and implement the strategic principles of human salvation.

But it is possible to give many examples, diverse politicized resolutions which seems to support the noospheric idea of V.I. Vernadsky about human relations to living systems and preservation of their diversity.

However, the conflicts in Ukraine and the international unbalanced relations between states at the planetary level remain a fruitless slogan for these important environmental issues. There is an unowned use of soil in monoculture, Polissia deforestation while ignoring scientific developments in Ukraine today. Medical industry is also in unbalanced situation as AIC. Every year we are increasingly becoming dependent on foreign vaccines, medicines, diagnostic devices. The plans for the establishment of a national Ukrainian depositary of virological objects were left in the backyard in the field of medicine, biology, which could be the key to the formation of biotechnologies of varying degrees of complexity for improving the population health and the state biosafety. One has to wonder that the country that has given impulse to virology science is not able to provide itself with vaccines against harmful viruses today. It should be taken into account for example, that the variants of the influenza virus are extremely variable and the vaccine must be prepared at the place of the population residence, where the relevant pathogen and its variants are distributed. Phagotherapy can be an extremely important scientific and industrial area in Ukraine today. Basing on scientific approaches it can significantly improve the state of human organisms, animals and plants. It is necessary to use modern scientific achievements for the formation of 
biopreparations using viruses of microorganisms for this purpose, considering their lytic and lysogenic properties, adaptation of bacteriophages to their respective hosts (bacteria) and other substantiated requirements of the technological process of this level. During the development of "advanced" technologies, humanity often loses control over their ultimate influence on living objects. Many negative examples can be cited as to the negative effects of the implementation of modern technologies in various fields of management in Ukraine and other countries. Such as pollution of space by spent structures; plastic utensils and other waste products penetration into the water systems; military action and using of deadly modern weapon of various types, including biological; deforestatin; emissions of chemical compounds to the atmosphere; accident at the NPP; inappropriate use of biological technologies, etc. These and other factors cause an abrupt climate change, loss of drinking water sources and reduce the agrocenoses productivity $[1,3,4]$.

It negatively affects the health of people and causes the destruction of all living things. In these situations, a significant change in the structure and function of viruses of different taxonomic groups occurs at a rapid pace. Under these conditions the HIV, Ebola, influenza and hepatitis viruses and other pathogens daily lead to high mortality in different regions of the planet. As an example of troubles in planetary ecology, the outbreak of Zika virus can be triggered which is transmitted by Aedes aegypti mosquitoes. This kind of mosquitoes is a carrier of the Dengue virus and yellow fever, which are distributed in Brazil and other countries. The pathways of the this pathogen appearance - laboratory-engineering (GM) or natural evolutionary. It must be admitted that the spread of the Zika virus is another warning to humankind of the possible collapse in wildlife under conditions of its barbaric use. It is worth noting that the induction of the virus and its increased pathogenicity can be reinforced by physical, chemical and biological factors formed in ecological chains mosquitoes.

Returning to the problem of mosquitoes, as the vector of viruses should be noted that in Ukraine this question at a high methodological level in $70-80$ years of the XX century was studied in a specialized laboratory created by professor of Taras Shevchenko National University of Kyiv O.P. Crystal. Achievements of this scientific center allowed us to successfully solve a number of applied and fundamental problems in the field of ecology and other related sciences.

These important problems are also part of the tasks in the field of veterinary and plant virology. It should be noted that the division of virology into branch chains is not a logical scientific approach. Analyzing the current studies there is a lot of common in the structure and function between viruses of mammalian, plants, bacteria, fungi and other organisms. In the 1960's, the XX century corresponding Member of the Academy of Sciences of the USSR professor S.M.Moskovets created a powerful scientific school of phytovirologists. He was a teacher for many of us, dreamed about creating an All-Ukrainian Institute of Virology. That is why, for example, global virological problems aimed at unification should be based on questions of general virology. Having the opportunity to evaluate research projects of the EU on biotechnology and virology in Brussels (1995), I want to emphasize that native developments of these problems often find a significant place in scientific projects of foreign biotechnology [1].

Unfortunately, a significant number of Ukrainian specialists migrate to foreign countries looking for a better luck. We believe that the time has come to return our young scholars to Ukraine with appropriate legislative support through their financial support for them and creating inter-branch laboratories and living system research centers. At the NAAS General Meeting in 2016 it was noted that agricultural academic science is an important chain for implementation of applied and fundamental challenges in AIC. The president of NAAS Academician Yaroslav Hadzalo stressed in his report that even with tight funding academy has significant and important development for Ukraine in the field of plant breeding and genetics, veterinary medicine, mechanization of agricultural production, system of water problems, ecology, soil science and technology in the field of agriculture, microbiology. But also a number of problems were identified that require an immediate solution. Such as land legislation; introduction into production of native biotechnology developments in the field of virology, molecular biology; saving of scientific schools and providing young professionals with reliable working and living conditions, support science and education by state authorities.

Every scientific institution of NAAS has developments which can be useful in AIC and in related fields of production in Ukraine. But bureaucratic approach to science, politicized solutions to its development and assessment by the state authorities push us into deep dependence and bowing to the foreign powers on these important problems of the present.

Let's give examples of scientific developments capable of improving management in various spheres of life:

- it was first proved that single cells of the plants meristem often are contaminated with viruses which in the conditions of biotechnological processes in vitro cause various diseases of plants. Institute of Microbiology and Virology of the NAAS studied hop and potatoes diseases [1]. For this technology, healthy donor plants were needed, which made it possible to obtain in 1.5-2 times the higher productivity of crops for black pepper 
(Vietnam). Even today this approach is ignored and deadlock production situation is made for native and foreign researchers; - in the early 80's of XX century together with Institute of Microbiology and Virology of the NASU and virology department of KNU by T. Shevchenko, and later with the Oncology Institute NASU experiments were conducted on the transfection of RNA-containing plant viruses in mammalian tumorsb based on our developments. In this case, many variants of VTM (plus Tobamovirus RNA) caused, under certain conditions, the "lysis" of HELA tumors and piglets testicles in cell culture $[1,7]$.

We received dozens of requests from foreign colleagues for these scientific results.

Moreover, some fragments of these technologies, I have marked in projects and foreign publications. Further analysis I leave for thoughts.

The other example is about development related to agro-industrial complex. It is worth noting that monoculture in agrocenoses, blind use of pesticides of various origins in fields, neglect of native varieties and technologies in agricultural production are unreasonable processed that greatly reduces the productivity of our soils. Here is another example. Most European countries use microfertilizers, organic preparations (stimulators of plant growth and development), insecticides according to traditional approaches - treatment of vegetative plants with appropriate solution. According to our calculations a certain agricultural crop in such conditions absorbs the active substance by only $3-10 \%$, and everything else disappears from the external factor (flushing, wind, drying, etc.). Our developments at the Institute of Agroecology and Environmental Management of NAAS provide an opportunity to approach this issue another way: estimation of information state of plants and use of biological preparations (together with NULES) on carriers of organic compounds. At the same time, the yield increases in different crops by $15-45 \%$ or more with the moderate exploitation of the technology of agrocenoses and the reduction of pathogens in plants $[1,5,10]$.

Other developments should be also admittedreduction of nitrogen fixation under conditions of a viral infection; the effects of radiation, magnetic fields and microgravity on pathogens, important directions on phage therapy issues, technologies for obtaining attenuated variants of viruses - can be a part of the technology of different quality. Among these studies application of important developments in the use of biochemical compounds of basidiomycetes mushrooms as stimulators of growth and development of plants and other organisms is promising in AIC ( NULES, Institute of Agroecology and Environmental Management of NAAS) [9]. Also the diagnostics and identification of viruses of different taxonomic groups, assessment of the stability of varieties, hybrids to viruses of hops, sunflower, soybeans, wheat, potatoes, tomatoes, buckwheat, black pepper, fruit and berry crops, etc.should be noted. In recent years the Institute of Agroecology and Environmental Management intensively investigate viruses of plant, fungi, forest ecosystems, organisms of water systems and soil [1,6, 9].

These and other studies have become the basis and holding of seven international conferences «Bioresources and viruses». The computer database of localization of phytoviruses in the soils of Ukraine was created on the base on years of researches together with virology department of KNU by T. Shevchenko $[1,10]$.

In recent years the Institute of Agroecology and Environmental Management became an unifying center for researches of various environmental issues in the agroindustrial complex. More than 650 varieties and hybrids of different crops were tested for virus-carrying and provided manufacturing recommendations for this problem.

\section{Conclusions}

Mastering of structural and functional properties of viruses of different taxonomic groups of humans, plants, animals and other organisms is extremely important for today's period of development of science of education and production.

Taking into account current developments in the field of virology problems, I want to appeal to native and foreign potential sponsors for possible financial support of submitted to the discussion scientific and research developments which are of strategic importance for Ukraine.

\section{Bibliography}

1. Boyko A.L. Osnovy ekolohiyi ta biofizyky virusiv/A.L. Boyko. - K.: Fitosotsiotsentr, 2003. - $164 \mathrm{~s}$.

2. Mikrobiolohiya, virusolohiya, imunolohiya; za red. V.P. Shyrobokova. — Vinnytsya: Nova knyha, 2011. — $952 \mathrm{~s}$.

3. Virus diseases of Cucurbitaceae plants of the territory of Ukraine/T.O. Rudneva, T.P. Shevchenko, I.G. Budzanivska et al.//Plant science. - 2006. — № 6. - P. $508-510$.

4. Lyubov' Kovalevskaya//Chernobыl' «DSP». - K.: Abrys, 1995. - S. 159 - 167.

5. Mel'nychuk M.D. Osnovy biotekhnolohiyi roslyn/M.D. Mel'nychuk, T.V. Novak, B.O. Levenko. - K.: Ey-BiSi, 2000. $-248 \mathrm{~s}$. 
6. Polishchuk V.P. Posibnyk z praktychnykh zanyat' do kursu «Zahal'na virusolohiya»/V.P. Polishchuk, I.H. Budzanivs'ka, T.P. Shevchenko. — K.: Fitosotsiotsentr, 2005. - $204 \mathrm{~s}$.

7. Vplyv VTM na funktsional'nu aktyvnist' mikrofahiv bilykh myshey/N.V. Taykova, T.O. Innatenko, S.S. Kur"yachenko, O.V. Molchanets'//2-ha mizhnar. konf. «Bioresursy ta virusy». — K., 1998. — S. 104.

8. Chernyuk S.O. Kharakterystyka izolyativ VTM roslyn zapovidnyka «Askaniya-Nova» ta Kanivs'koho derzhavnoho zapovidnyka/S.O. Chernyuk, S.S. Kyr"yachenko//Visn. KNU imeni Tarasa Shevchenka. - Ser. Introduktsiya ta zberezhennya roslynnoho riznomanittya. - 2000. - Vyp. 3. - S. 69-71.

9. Boyko O.A. Morfolohiya ta strukturni osoblyvosti patoheniv Basidiomycetes/O.A. Boyko, T.P. Shevchenko, A.A. Boyko//Mikrobiol. zhurn. - 2013. - T. 75, № 3. - S. $56-61$.

10. Mishchenko L.T. Rozsiyuvannya polyaryzovanoho lazernoho vyprominyuvannya lystkamy pshenytsi sortu Apohey za umov model'ovanoyi mikrohravitatsiyi/L.T. Mishchenko, S.M. Savenkov, S.A. Oberelyuk//Kosmichna nauka i tekhnolohiya. - 2004. - №1. - S. 91 - 98. 